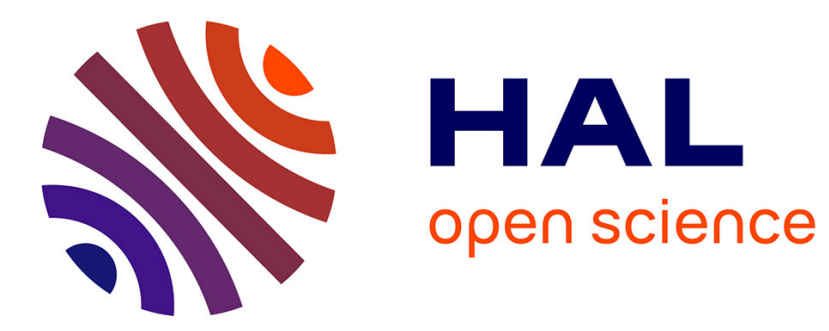

\title{
Local Powers and Judicial Constraints in a Case of Rape in India
}

Daniela Berti

\section{To cite this version:}

Daniela Berti. Local Powers and Judicial Constraints in a Case of Rape in India. Diogenes (Engl. ed.), 2015, Diogenes, 60 (3-4), 10.1177/0392192115589274 • hal-01247626

\section{HAL Id: hal-01247626 \\ https://hal.science/hal-01247626}

Submitted on 22 Dec 2015

HAL is a multi-disciplinary open access archive for the deposit and dissemination of scientific research documents, whether they are published or not. The documents may come from teaching and research institutions in France or abroad, or from public or private research centers.
L'archive ouverte pluridisciplinaire HAL, est destinée au dépôt et à la diffusion de documents scientifiques de niveau recherche, publiés ou non, émanant des établissements d'enseignement et de recherche français ou étrangers, des laboratoires publics ou privés. 
[Published in: Daniela Berti \& Gilles Tarabout (eds), 2015, special issue of Diogenes, vol. 60 (3-4) - translation of Diogène 239-240, Aux Frontières de la loi. Justice, pouvoirs, et politique, 2013] [pp.97-115]

/p. 97/

\title{
Local Powers and Judicial Constraints in a Case of Rape in India
}

\author{
Daniela Berti ${ }^{1}$ \\ CEH-CNRS, France
}

An article recently published in the Indian press and entitled Police to videograph evidence announced that the police of the North Indian state of Himachal Pradesh, whose main police stations in the region have been equipped with digital video-cameras, will from now on be required to include in their files a filmed recording of witnesses' statements (The Tribune, Himachal Pradesh edition, dated 25 July 2011). The article went on to explain the purpose of this measure: to avoid the situation whereby, when a case comes to trial, the witnesses for the prosecution, including the victims of a crime, deny what they told the police during the enquiry stage, thus becoming, in common law parlance, 'hostile witnesses', witnesses who retract their testimony. Such retractions during a trial regularly occur in the courts of the subcontinent, both in important and highly publicized cases and in routine judicial affairs. They often provoke in prosecutors as in judges an attitude of resignation and impotence.

In a judicial practice marked by a proliferation of written documents, the idea of introducing video recording to support the provision of judicial proof, while showing a devaluation of the written word, is also a sign of a certain distrust in orality. It thus questions the very principle on which the system of common law is based, that judicial truth must be established through the oral evidence the witness instantly provides at the time of the trial (Davies, Croall and Tyrer, 1995). This 'principle of orality', prescribed by a code of penal procedure which was introduced into India by the British, stands in 
counterpoint to the idea that judges and prosecutors constantly reiterate, whereby most of the witnesses who are called to give evidence to support the indictment deny in court what they previously declared to the police. This principle also seems, in a certain way, to be contradicted by a predominance of the written word which characterizes the trial procedure in India, which envisages the long and meticulous translation and transcription of what is said at the time of the hearing (Berti, 2010, 2011a).

In this article, I analyse this contrasting relationship between the written and the oral in the production of judicial proof, in particular in relation to the problem posed by hostile witnesses. I base my findings on a criminal case which I observed at a district court concerning the rape of an under-age girl in order to analyse how judicial procedures come to be perturbed by extra-judicial /p. 98/ power dynamics resulting from local relationships of dominance. This is a crucial point within a more general issue which authors interested in the functioning of courts in India have addressed on various occasions. How can a system of justice, inherited from colonial society and centred on a regime of proof and truth derived from elsewhere, function within a society which remains largely based on hierarchical relationships and local dominance, relationships which are centred on religion, gender, caste status and economic dependence, as well as on feudal, family or territorial allegiances? How can state justice, which is independent and secular, function when faced with these multiple highly coercive spheres of authority, particularly in the rural milieu?

The first authors to have considered this question, from the 1960s onwards, referred to a 'clash of the values' between an alien state and indigenous society (Cohn, 1959), or between law-based jurisprudence and local jurisprudence (Cohn, 1965). Two types of considerations have followed on from that. On the one hand, the difficulty in applying state justice within a village community could be analysed, from the perspective of subaltern studies, in terms of 'resistance' to the colonial and post-colonial authority. ${ }^{2}$ On the other hand, the fact that state justice can on the contrary sometimes be preferred by villagers, depending on the vested interest they can derive from it, has been interpreted in terms of 'manipulation' or of strategic calculation (Cohn, 1959). The two attitudes can moreover be compatible, as shown by the notion of bi-legality, introduced by the 
anthropologist M. N. Srinivas and subsequently taken up by several other authors (Galanter, 1992; Shah, 1998).

The colonial, or post-colonial, specificity of the dissonance between a justice system dictated by the state and multiple forms of local authority has been criticized by Anderson (1990) who, relying on historiographical work bearing on the mediaeval period, underlined the fact that such a gap already existed during the pre-colonial period in the relationships between kingdoms and other forms of more localized power (Stein, 1980). Besides, the dyadic opposition between 'indigenous' and 'alien' presupposed, according to this author, 'a sociocultural uniformity on either side of the dichotomy which probably does not exist' (Anderson, 1990: 172).

Other studies devoted to the question of the functioning of the justice system in India have revealed the disparity between the 'promises' of legal reform (Anderson, 1990: 175) aimed at putting an end to different types of social inequality, and the disfunctionality of the judicial system or of its functionaries, which would prevent the realization of these promises and would reproduce, in practice, the same dominance relationships that are proposed to be eradicated.

One approach which avoids falling into the 'dualist trap' of opposing the 'alien state' and local practices, or the hegemonic and the subaltern, is the one that was adopted outside the Indian context by Merry (2003), in her study concerning the victims of domestic violence among North American working class populations. In this work, the author ponders the question of understanding how various persons end up choosing to involve the state justice system instead of remaining bound by the dynamics of dominance centred on the family, religion or the community. How does a person come to understand her or his problem in terms of rights and to see her- or himself as a rightsbearing subject? Basing herself on several case studies, Merry shows how the fact of perceiving oneself as a subject with rights depends on a positive experience of the judicial system (police, prosecutors, judges). The author also refers to the notion of 'multiple and potentially contradictory subjectivities', introduced by Moore (1994), according to which each individual 'takes up multiple subject positions within a range of discourses and social practices, so that a single subject is not the same as a single individual' (in Merry, 2003: 349). 
This attention brought to the multiple subjective positions of persons belonging to a same social milieu marked by a situation of oppression allows for a more nuanced and more diversified framework of the relationship between state justice and local dynamics of dominance. This may moreover be applied not only to victims but also to the representatives of the justice system (judges, /p. 99/ prosecutors, police) with whom the victims find themselves interacting. It is within this perspective that the case here will be analysed. It features protagonists - whether on the side of the judicial system or that of the civil parties - whose behaviour is neither fixed nor devoid of ambiguity, and who, according to the moment, may seek the affirmation of the law or, to the contrary, may reproduce the dominance relations prevailing at village level.

In the first instance I will briefly review the principal stages of the Indian judicial procedure, to show how in particular the ambiguous rapport between the oral and the written is manifest in the cases of key witnesses who retract their testimony, the so-called hostile witnesses. I will then go into the detail of a particular case so as to show how the unfolding of the trial is determined by the social dynamics of the affair concerned.

\section{Between the oral and the written}

An initial question that can be considered when we are studying a criminal case in India consists of asking how the crime has been described (or denied) by the parties involved. The recording of a case by the police draws out of those close to the victim or the accused a multiplicity of narratives bringing multiple and contrasting points of view, opinions, rumours and revelations. In contrast to the ethnologist, for whom all such narratives are considered legitimate for his case study, the specificity of the judicial process requires that these sources of information can only be taken into account by the judge if they have been introduced by way of the court procedure - whether this be in their written form as complaints or police reports, or in their oral form, through the statements of witnesses at the court sittings.

The value assigned to the written statements and oral declarations during the production of these narratives varies according to the way the case proceeds. Thus, statements taken from witnesses and drawn up by the police do not have the value of evidence, for, as 
we have seen, what has been transcribed during the enquiry must be confirmed orally by the witness at the trial. What the witness says during the court hearings in reply to questions he is asked will then be put into written form (still in the form of a narrative) so that judges of a higher court can consider this testimony in the case of an appeal. As Roussel (2005: 23) remarks in relation to the inquisitory procedure followed in France, here too, only more so, the process relies on 'an incessant toggle between the oral and the written in subtle interplays of refutations and confirmations, interferences and references'. But what kind of narratives are we dealing with?

If we are to consider solely the written documents, the first version of the narrative to be included in the indictment file corresponds to the First Information Report (FIR). The FIR is drawn up by the police following upon a complaint (whether oral or written) or directly by a police officer. It is in the form of a narration written in the first person by the complainant, even though it is always actually drawn up by the police. The account of facts is already presented as a legally formatted version which follows precise criteria of the judicial procedure. When the FIR is compiled following a written complaint (from the victim or her or his representative), the latter is also included in the file. The complaint thus precedes the version of the narrative reported in the FIR, but it only takes on value from a judicial point of view if it prompts the police to register the case.

Once the enquiry has been launched, witnesses' depositions throw light on other aspects of the narrative. The transcriptions of these interviews are written out by the police and are in the form of narratives recounted in the first person by the witness, even though they transcribe an interaction effected in the form of question-and-answer. These transcriptions are not signed by the witnesses. Without constituting 'evidence' as such, they will nevertheless serve as a 'basis for indictment' (Roussel, 2005: 17) from which the questions which will be directed to the witnesses at the trial /p. 100/ will be formulated. These transcriptions are regularly challenged by witnesses who deny at the time of trial having actually said what the police have written down.

Among the initial documents of the judicial file also figures the police diary, the field notes drawn up on a daily basis by the police over the course of the enquiry. These notes include the questions put to the accused during his time in police custody. The transcription by the police of his replies, contrary to the transcriptions of the 
questioning of witnesses, will scarcely if at all be taken into account during the trial. In contrast to what happens in France, where the aim is always to arrive at a confession (Roussel, 2005: 19), courts in India will generally expect that the accused, often on the instruction of his lawyer, will plead not guilty and will deny the facts. It may well happen that, in the police report, the accused may have partially admitted the facts, but that, when appearing before the judge, he denies all the charges without anyone taking into account what the police had written in their report. Moreover, the voice of the accused will not be solicited during the trial, except when all the witnesses have been heard: he is then presented, in very procedural fashion, with a long list of charges (cf. infra).

The beginning of the trial will remain in the court file in the form of recorded evidence, that is to say the transcriptions of the oral testimonies made by the witnesses during the court sitting. This recorded evidence marks the passage of the file from Hindi into English. ${ }^{4}$ During the sittings of the court, as the witness replies (in Hindi) to the questions put to him or her, the judge summarizes the witness's examination in English by transforming it into a narrative made by the witness in the first person. The transcribed narratives of this admitted evidence become the most consulted parts of the court transcript. They are re-read and quoted from by the judge in the drafting of his judgment, and also by the judges of higher courts in cases of appeal.

In relation to the earlier forms of narrative mentioned, these evidential narratives present a new element. They are not limited simply to transforming a process of question-and-answer into a narration, but also indicate what in this narration is held to be false by the side that is putting the questions. This passing from the 'presumed true' to the 'presumed false' is marked in the narrative by what is called in common law parlance the 'cross-examination', which corresponds to the questions put to the witness by the opposing party (for example, by counsel for the defence to the witnesses for the prosecution). In contrast to the examination-in-chief, where the witness has freedom as to the form of reply he or she may use to the questions put, in the cross-examination he or she can only either confirm or deny what is suggested in the question (called leading questions): he or she must reply 'yes' or 'no'. These questions tend more to be used so that the questioner can insinuate an affirmation 
rather than obtain an answer, since often the questioner knows in advance whether the witness will confirm or deny what is suggested by the question. Over the course of the transcription of the session, the leading questions are very important, because they are not only spoken but also translated into English and transformed into a narrative in the first person made by the witness. Contrary to the examination-in-chief, here each sentence of the narrative is introduced by the formula 'it is incorrect (or correct) that' or 'it is not true (or it is true) that' - signifying that the witness denies or confirms what the question insinuates. The result can be a narrative where, paradoxically, the person narrating it denies little by little what is said (Berti, 2011b).

If the cross-examination of witnesses by the opposite party is part of the ordinary course of the trial, what becomes effectively a cross-examination of a witness by the party who had summoned that witness to the bar can appear as a perturbation of the flow of the trial, and hence the credibility of the witness comes to be put in doubt. This is what happens very often with witnesses for the prosecution turned 'hostile' when they are questioned by the prosecutor or by the judge himself: they begin by denying what they are supposed to have told police during the enquiry stage. In such circumstances, interactions then start to become tense. The witness is accused (in the name of the prosecutor) of not telling the truth, even though this may simply be a procedural accusation made /p. 101/ so as to be noted on the level of the written record, in the transcription of the session. It is at this point that the judge interrupts the linearity of the narrative which he has been dictating from the question-and-answer exchanges which he has been presiding. He has his clerk inscribe the following sentence:

At this stage Learned Public Prosecutor has stated that witness is trying to suppress the truth. As such, prayer is made to cross-examine the witness, which is considered and allowed.

This formula is dictated directly in English, without the witness, who in general speaks only either Hindi or the local language or dialect of his region, being able to understand it. It is often pronounced directly by the judge, while still being presented as a request emanating from the prosecutor. It is moreover the judge who directs the majority of the questions to the witness, especially if he sees that the prosecutor has not sufficiently prepared the case or is not 
sufficiently combative to confront a reticent witness. Urged by the higher courts not to remain a passive spectator of the trial, the district court judge often will intervene in the interactions by directly questioning the witnesses himself, whether it be during the examination-in-chief or the cross-examination. Being the only person having to reach a decision - the jury system was abolished in India in 1960 - he has no need to explain the technical aspects of the procedure. When he dictates to the court-clerk that the witness will now be subject to a cross-examination, the latter is not informed that from that moment on the veracity of what he has said is now in doubt and that the questions will henceforth serve to demonstrate his lack of credibility.

At the end of the presentation of the evidence, the facts are once again narrated during the 'statement of the accused', as prescribed by section 313 of the Indian Evidence Act. The accusations presented over the course of the court sessions are submitted to the accused so that he or she might answer them. This part of the trial generally does not reserve any surprises. The questions are prepared in advance on the basis of the transcriptions of the previous sessions. 'It has come in the prosecution evidence led against you that [...]. What have you to say?' To each question the accused replies: 'it is incorrect', or else 'it is wrong' or else 'I don't know' in a more or less automatic fashion. ${ }^{5}$ The 'statement of the accused' is thus usually presented as a long series of questions followed by the same type of reply. It is only at the end of the listed questions that the reply can sometimes include supplementary information, as when the accused is asked: 'Why has this case been registered against you?' The witness then repeats what his counsel may have already intimated several times during the cross-examination - for example, that the case had been fabricated by the police or by a personal enemy.

The following stage corresponds to the closing arguments of both parties, during which the prosecutor and the defence counsel defend their positions before the judge. During this process the transcribed evidence is re-read and argued with reference to precedents, but nothing is retranscribed. The judge sums up the facts in the order they were presented by the successive witnesses in the trial, as well as the arguments for the prosecution and the defence, then, basing himself also on any legal precedents, he determines the case by giving his decision. 
This multiplicity of narratives elicits two principal observations. The importance accorded to transforming verbal exchanges into judicially appropriate written language should first be noted. For, although on the one hand, in conformity with common law procedures, oral testimony retains its importance in relation to the written, on the other hand all that is spoken is transformed by a process of writing which puts the question-answer exchanges into the form of a narrative in the first person and which translates oral Hindi into legal English. Secondly, the importance of the questions compared to the answers should be noted. In the context of the interactions, the aim of the questions is not so much to elicit a reply as to render explicit a counter-narrative which will be set firm in the written English version which becomes the official version.

\section{/p. 102/}

Taking account of this multiplicity of narratives, I will now analyse a particular case to show how this tension between the oral and the written is not the only consequence of the official transcription of an oral interaction with a police officer or a justice professional. It also relates to developments in the case for the parties involved, and to the negotiations, pressures and proposals made at the local level and outside of the court. In order to understand what happens at the time of a trial, one must take into account not only official versions that are included in the court record, but also discourses that people involved in the affair - the civil parties, the witnesses and the professionals can have outside of the courtroom.

\section{A double crime}

The case presented here corresponds to a circumstance considered to be fairly common in India: the sexual exploitation of a lower caste woman by a high caste man. The accused was Dhiman Sharma, a young man belonging to a Brahmin caste, aged around 20, from an isolated village in the mountains some three or four hours by road from Shimla, the capital of the State of Himachal Pradesh. The victim, Anita, was a girl from the same village, was 11 years old at the time of the trial (in 2010). She belonged to a caste of very low status (Koli) included among the Scheduled Castes, an administrative category which applies to those castes formerly referred to as 
'untouchables' and which benefit from protection under the Indian Constitution and under new laws outlawing discrimination. Anita was living with her mother and her small brother in the home of the young man's parents, for whom her mother worked as a servant.

The First Information Report (FIR) drawn up by the police in July 2009 covered three sections of the Indian Penal Code: section 376 , which fixed the sentence for rape as imprisonment 'for a term which shall not be less than seven years but which may be for life or for a term which may extend to ten years'; section 354, which related to an 'assault or criminal force to woman with intent to outrage her modesty'; and section 506 covering 'criminal intimidation'.

According to the Indian Penal Code, rape is a 'cognizable offence', that is to say, the person accused may be immediately placed under arrest, without a conditional release under bail being able to be granted. It is equally regarded as a 'non-compoundable' offence, meaning that it cannot be resolved by a private compromise between the parties concerned, as it is considered an offence also committed against the society. No withdrawal of complaint is thus possible and the trial must proceed until a verdict is handed down by a judge of a court at the district level (a Session Judge). Furthermore, the case was registered under section 3 of the Scheduled Castes and Scheduled Tribes Prevention of Atrocities Act (hereafter referred to as the $\mathrm{Sc} / \mathrm{St}$ Act), promulgated in 1989 by the Parliament in order to prevent 'offences or atrocities against the members of the Scheduled Castes and the Scheduled Tribes'. More precisely, the section of the $\mathrm{Sc} / \mathrm{St}$ Act invoked for this case declares punishable

Whoever, not being a member of a Scheduled Caste or a Scheduled Tribe, [...] being in a position to dominate the will of a woman belonging to a Scheduled Caste or a Scheduled Tribe and uses that position to exploit her sexually to which she would not have otherwise agreed. (Sc/St Act, Ch. II, Sec. 3 (1) (xii)) ${ }^{9}$

The registration of a charge of rape under the $\mathrm{Sc} / \mathrm{St}$ Act induces several procedural constraints, among which is the requirement that the police officer authorized to conduct any enquiry be an officer of a rank at least equal to that of Assistant Superintendent of Police. This requirement prescribed by the law is intended to ensure that this type of case, defined as being 'highly 
sensitive', is treated in an appropriate manner. ${ }^{10}$ In such cases, furthermore, the suspect (always referred to in India as 'the accused', while still being considered innocent from the procedural point of view) is $/ \mathbf{p} . \mathbf{1 0 3} /$ then considered to have committed the crime of which he stands accused, and it is incumbent on him to furnish proof of his innocence.

These dispositions are perceived as being very constricting by the castes considered of high status. This explains the commentaries often advanced in the media, which claim that the $\mathrm{Sc} / \mathrm{St}$ Act is perverted and manipulated by the lower castes, said to be easily tempted into making false accusations against a member of a higher caste in a judicial affair.

However, among the Scheduled Castes, only part of the population is aware of the existence of this law, whose complete text exists only in English. The degree of knowledge that villagers of these castes can have of their rights therefore depends on several factors, among which is the presence in their region of political leaders belonging themselves to the Scheduled Castes. These latter bring up such legal issues during their public speeches or through local newspapers. Some of these leaders define themselves also as 'social activists' who, having acquired a certain competence with respect to judicial procedures, can assist the members of the Scheduled Castes to invoke the laws that the state has promulgated in their favour.

This is what occurred in the case under discussion. The registration of the case followed upon a complaint addressed to the Superintendent of Police (SP) by Karam Chand Bhatia, himself a member of a scheduled caste, but who had no prior direct connection with the victim who previously had never met him.

Before getting into the detail of the trial, let us examine how this Karam Chand Bhatia ended up becoming the complainant, which will also allow me briefly to set out the case as it was told to me by that activist.

\section{Social activism and judicial mediation}

Karam Chand Bhatia is a member of the Chamar (leather-worker) caste, and has a little shoe shop in the town of Shimla right next to the District Court. 
$\mathrm{He}$ is also the regional leader of a political party founded in 2009 as an offshoot of the Bahujan Samaj Party (BSP), whose ideology defends the rights of the Scheduled Castes and Scheduled Tribes. In this role, he takes part in political meetings, builds connections locally and nationally, and was at the time preparing to stand as a candidate in the forthcoming regional elections. But Karam Chand endeavours to keep his political identity separate from what he defines as his 'dharmic' activity, which he relates to his presidency of the Sant Shree Ravi Dass Dharm Saabha, an organization he himself founded and which takes its inspiration from the teachings of the guru Ravidass (15th century), to which many of the Chamars show deference. It is by emphasizing this dharmic role that Karam Chand pursues his court activities by helping the people of the Scheduled Castes to report the abuses committed against them by high-caste people. He assists them to put a complaint in writing, or else draws it up in his name if they fear reprisal. In his little shop, where he sells and repairs shoes, he piles up enormous heaps of files containing different sorts of legal documents - official letters, copies of complaints - along with numerous newspaper articles carefully cut out, dated and stuck into exercise books, all concerning the lower castes, or sometimes, relating to political gatherings. This role of being an intermediary between the poorest and most oppressed of the society and the judicial system of the state is not exceptional in India. On the one hand, it is the consequence of the gap that exists between well-meaning anti-discriminatory measures taken at the legislative level and the impossibility for still very underprivileged people to demand their rights when they find themselves in positions of subordination or dependence with respect to the higher castes. On the other hand, it also shows the possibility open to members of the lower castes to carve out for themselves a public place in society, whether it be as court intermediaries or as politicians.

\section{/p. 104/}

Thus, in his little shoe shop, Karam Chand is very much in demand, not only by the lower castes, but also by local neighbours who do not belong to the Scheduled Castes but who come to him for help in drawing up a document addressed to the court or to learn how to proceed in their legal cases. Though knowing nothing about English or the law (he has law statutes translated by an English-speaking friend), Karam Chand is passionately devoted to this role as legal 
consultant, a role which has earned him recognition from the judges and lawyers of the city - who speak of him as a social worker or humanitarian activist. He is also known by the local journalists, through whom he is trying to ensure that pressure is brought for discrimination against the Scheduled Castes to receive public attention.

It was effectively through the intermediary of a journalist that Karam Chand was contacted for the case in question. The little brother of the raped girl, who was seven years old, had first been taken to the police station with the help of a member of his village. But the police officer, in view of his young age, asked him to come back with a written complaint, signed by an adult, before he could officially register the matter. On the advice of the journalist, the adult accompanying the boy then contacted Karam Chand to ask for help.

When he was telling me about the case, Karam Chand said that at the beginning he did not want to get involved with the matter. $\mathrm{He}$ knew that rape cases were very difficult to prove, for the victims 'firstly agree to talk, then they reach a compromise with the other party and in the end they deny everything before the judge. But - he went on - when I saw that it was a very young girl I accepted the commission...'

He recounted what the little brother of the victim had told him: when his sister was asleep (with her family in the house of their Brahmin master) Dhiman (the accused) 'tied up her mouth and undid the string of her salwar (Indian pyjama-like trousers) while she was crying out'. He told me also that at the school the woman teacher had noticed spots of blood on the girl's trousers; she had asked her what had happened. First of all the girl had not wanted to say anything to the teacher, but then she told her everything and said that 'Mamu (Uncle) did those things with me'.

Karam Chand then drew up the complaint addressed to the Superintendent of Police, giving some further details: that the girl's mother, who was divorced, had been working for four years for the father of the accused. He made clear that 'the mother and the victim are of the Koli scheduled caste' and concluded by saying that 'because of this fact, you are asked to act immediately and to register the FIR against the accused man. The accused should not be protected.'

The FIR was indeed registered and the accused placed in preventive detention. The item appeared in the newspapers under the 
heading 'Ten-year-old raped for two months: one held' (Hindustan Times, Chandigarh, 2 August 2009).

\section{Looking for the victim}

During the trial, when I began to follow the case in March 2010, I was able to have several discussions with the Assistant Superintendent of Police (ASP) who had conducted the enquiry. He told me that when he had gone to the village to begin investigations following upon the complaint that had been laid, the mother and her daughter had disappeared: 'We looked for them for a whole night, scrambling around in the mountains [...]. I was even stung by insects, the conditions were really difficult. Then I called the father [of the accused] and I said to him: "You have killed them and I am going to charge you". The next day, Anita and her mother appeared of their own accord, but stubbornly denied everything. I put pressure on the mother, saying to her: 'You are her mum, so as a mother how can you act like this?' So then she told me everything that had happened down there. And I drew up the deposition.'

\section{/p. 105/}

The ASP then went on: 'The medical report was clear. If you read the report you would have tears in your eyes. This little girl was only nine years old! She was tiny and so thin! She was not in very good health.' In the ASP's view, the medical report provided a very solid piece of evidence, which would have allowed the prosecutor to prove the guilt of the accused even if the witnesses changed their story before the court. He mentioned also that there was the testimony of Karam Chand (the author of the complaint) and of the school-teacher, 'two credible and respectable witnesses' who in his opinion would no doubt have confirmed the accusations. He said that some of his colleagues had tried to dissuade him from entering the case since, if the victims were reticent, there was no doubt a risk that they would retract at the moment of the trial. But, he declared, 'it was my duty as a police officer to undertake it, and if I didn't, then the girl would continue to suffer ongoing rape. I am not doing this for the sake of publicity. I do not know those people and I have not taken anything from them. We also have children at home, and if anything like this happened to them, we would be shattered.' 
The ASP's words should be understood in the context of the criticism sometimes directed at the police for entering (or not entering) cases following outside pressure - whether this be from economic interest or political influence or simply because of the links a police officer may have with one or other of the parties. It is also said, particularly among professionals of the justice sector, that the police are on the lookout for cases, that they want to please their superiors to show them how effective they are and so obtain promotions. It is especially during the trial itself that policemen come under scrutiny, for they may well be accused by the defence during cross-examination of having totally fabricated evidence for the case. This happens in cases which have been entered directly by the police, where the police are the only persons who confirm the accusations before the judge whereas the other witnesses deny them en bloc. In the case presented here, the FIR was drawn up subsequent to a complaint: it would thus be the complainant who would be first targeted by the defence.

\section{The trial}

The story of the rape was confirmed by the complainant (Karam Chand) when he was called to give evidence, but contested by the lawyer for the defence. In the written transcript of the cross-examination that he made of Karam Chand, the lawyer's line of argument can immediately be perceived by looking at the final sentence, which he dictated to the court typist without even having put the question to the witness. It is in effect a summarizing sentence which certifies that the witness is not in agreement with the conclusion that the lawyer put regarding the matter:

It is wrong to suggest that the present complaint has been falsely written by me in connivance with the enemies of the father of the accused.

This sentence insinuates that the case results from a plot between the enemies of the accused's father and certain members of the village to get their enemy into difficulties. The argument of a plot as the originator of a 'false charge' is systematically invoked by defence lawyers and is part of the general routine of trials in India. It 
happens that the lawyers may be even more explicit, by designating specific persons - often acquaintances of the accused - and even sometimes summoning witnesses to corroborate their theories. ${ }^{13}$ In the case at hand, the idea of a plot is presented more anonymously since it rests on the idea, which is generally shared, of a tension between the lower and higher castes at the local level. The court is thus indirectly painted by the defence lawyer as the place where the lower castes, thanks to the laws that the state has promulgated in their favour, can /p. 106/ come to 'avenge' their position of subordination at the village level, where they can benefit from a more favourable balance of power or exercise a pressure that they did not have before.

In the transcript of the evidence of Anita's school-teacher, heard next by the judge, the story of the rape is told from the viewpoint of what happened at the school, when the girl had undergone a medical examination. Via the questions put to her during the court session, the teacher, who is of the same high caste as the accused, stated that one day at school Anita was not her usual self. She was in a corner crying by herself. The teacher came over and discovered spots of blood on her salwar. She asked what had happened. The girl, after much insistence on the teacher's part, told her, crying, what had happened to her, giving the young man's name as well. The teacher then sent the girl to a social worker who took her to the hospital for an examination.

She also called Anita's mother and when she told her what Anita had said to her, the mother began crying and told her that the young man had been doing that for two years, but that she was absolutely powerless to prevent it, and asked to be helped.

The teacher thus confirmed before the judge the version that she had previously given to the police: that the girl had spoken to her about the problem and that she had revealed the identity of the aggressor. Furthermore, the lady doctor who examined the girl confirmed in court that the girl's hymen had been ruptured. Here is a part of her testimony:

I medically checked Anita and found bleeding from her private parts. I asked the cause, upon which Anita disclosed that one boy named Dhiman had sexually assaulted her due to which she was bleeding. I advised her [i.e. the social worker who accompanied Anita to the doctor] to report the matter to the police. 
Although the evidence of the doctor, the teacher and the activist all pointed the same way as the charge, the principal problem for the prosecutor came from the victim herself and her mother who, when it came to the trial, denied everything they had previously said to the teacher and the police. Questioned by the prosecutor, Anita said that neither she, nor her mother, nor her brother, had ever lived in the accused's house; that she always slept with her mother and her brother in the same room, and that the accused, whom she called her mamu (uncle) had never been to see her in the bedroom and had never assaulted her.

At this point the judge dictated the formula used to introduce a cross-examination:

At this stage, the learned Public Prosecutor has put forth a request that he be allowed to cross-examine the witness because the witness has resiled from her previous statement. Allowed.

In the cross-examination, the judge and the prosecutor took Anita back through all that she had stated in the police report, which they asked her to confirm point by point. ${ }^{16}$ The girl replied in the negative to all these questions, but these points would be translated into English and retranscribed in the court record. Another account emerged then through its very negation, introduced by 'it is incorrect that ...'

Below is an extract from the transcript made during the trial:

It is incorrect that during those days, accused Dhiman Sharma used to come and sleep on the cot in our room and whenever my mother and brother used to sleep, the accused used to lift me and put me upon him and thereafter used to open the string of my salwar and thereafter used to put his fingers in my vagina and thereafter his penis in my vagina and when I used to cry the accused used to gag my mouth and threatened me that in case I disclosed the said facts to anybody, he would kill me. She was confronted with [indications to references of the police file] where this had been recorded.

The accusations become more explicit and more aggressive because it is now a cross-examination: the question is formulated in detail by the person questioning the one who is supposed to /p. 107/ 
be their own witness, but who is now retracting the evidence and turning hostile. Below are a few passages from these interactions transcribed during the trial:

It is incorrect that my brother Hemant has also seen me naked with the accused upon which the accused had threatened him that in case he disclosed the said fact to anybody, he would be killed nor I had stated the said fact to the police (confronted with....). I never disclosed to Madam Gayatri [the teacher] that the accused Dhiman used to commit the aforesaid statement... It is incorrect that I had disclosed the said fact to the doctor ... It is incorrect that whenever the accused committed sexual intercourse, my vagina used to bleed nor I stated so to the police.

At the end of the cross-examination, the questions put by the prosecutor and the judge were separated from the police report to advance the reasons why the witness might not be telling the truth.

It is incorrect that, out of fear, I am not telling the truth. I am not telling lie. I am telling truth. Nobody influenced me. My sub caste is Koli hence a member of Scheduled caste. Accused Dhiman Sharma is a member of nonscheduled caste.

By this set of sentences (dictated without the question being asked, and in English without any understanding by the witness) the judge was suggesting, in the name of the prosecutor, that the girl was telling lies, and that she was lying because, being of the Koli caste, she was under pressure from the accused who was of high caste.

The same theory was put forward when the victim's mother was called to testify before the judge. He also declared her to be a hostile witness (again in the name of the prosecutor), and at the end of the cross-examination directly dictated to the court typist a set of statements pronounced as by the witness:

We belong to the same village. We are used to meeting whenever there is work. It is wrong to suggest that now I have received some consideration from the father of the accused and that now I am deposing falsely in order to save the accused.

The trial lasted several weeks, ${ }^{17}$ but from the time that the girl and her mother had gone back on their accusations, the prosecutor 
knew that the accused was probably going to be acquitted. While the hearing of the witnesses was still proceeding, I went several times to see him in his office. He was a man of refined nature, devoted to spiritualism and meditation, who liked to emphasize the social context rather than the legal aspects of the cases he was involved in. Indeed, it was he who first mentioned this case to me, as it moved him deeply and occupied his thoughts even at night. He told me that the social dimension would surely be of interest to me and urged me several times to go and see on site what was going on in the village, so that I might gain an understanding of why the girl and her mother had turned hostile. He was still incredulous: how had they been able to deny everything in front of the judge? 'Yes, he said, I could have had them charged for lying in court. But to what end? The girl had been raped, and she would then be punished for having lied? What would be achieved by that?' He blamed society, the problem of poverty and the domination of women by men. But he also blamed the state, whose duty it was, he said, to protect the witnesses. 'She [the mother] should have [been] removed from the company of the accused and kept there and given some employment. Otherwise, what could Mr Kocchar [himself] and Mr Gupta [the judge] do? [...] Sometimes, you know, when you are in court and you hear lies, lies and more lies ... it sends you mad! A single statement of mother could have been enough. But even now, the girl's mother is kept by the father of the accused, she is living in his house, that is the reason for her turning hostile!'

\section{/p. 108/}

He was also furious with an incident during the court sitting:

when the girl was in the court and I asked her what had happened and she turned to tell me, at that time the defense lawyer pulled her back and she did not tell me, and I really got angry and told the lawyer "what is this nonsense? Why did you pull her?" [...] I was really angry. I tried everything to get her tell the truth, I even showed her some photos for her to choose which person had done that to her. If the mother had not retracted her evidence, I would not have called the girl to testify. She was only nine... But since the mother had acted as she had, I decided to question her [the girl] with the hope that she might say something.

Although discouraged, he said he had not given up hope of winning the case. He would now take another line of argument. 'Why 
would the school-teacher have lied - he said - Did she have any animosity towards the accused? There was none at all. He [the judge] will tell me that this is hearsay and circumstantial evidence. But I will say that it is more than that. They saw blood on the carpet where only the girl herself had been sitting. There is also the medical report. Why would the doctor have supported the accusation if she did not think it was true?'

As it turned out, at the time of the closing arguments, the judged remarked that, because the girl and her mother had turned hostile, the three testimonies which could have served to corroborate the charge (that of the teacher, the activist and the doctor) were henceforth ruled inadmissible: they had become simply hearsay.

During the verbal exchanges that took place during the closing arguments, the judge, while intimating that the accused would be acquitted, directed a question to the defence lawyer which showed the importance given to the social dimension of the case. 'What does society have to say about this? What is being said in the media?' he asked. The defence counsel replied that at the time of the enquiry there had been articles in newspapers and a lot of media pressure, but now everything had calmed down. He added also that 'besides, if decisions are to be made based on the media, there is no point coming to the court!'.

The prosecutor then spoke again by highlighting the medical report which showed that the girl 'had been subjected to sexual intercourse', and that she was still bleeding when the medical check had taken place. The counsel for the defence argued that the bleeding could be due to an injury that she could have caused herself while playing with an external object - a notion that is constantly advanced in this sort of affair. Although the judge did not adopt in his deciding statement the defence counsel's hypothesis, he wrote that 'the prosecution was bound to prove the said fact [that she had been subjected to a sexual act by the accused] on the basis of testimony of the prosecutrix or any other witness.'At the conclusion of the summations, and confronted with the protests of the prosecutor who insisted that justice should be rendered independently of any private negotiations between the parties, the judge replied resignedly: 'What can be done now? Justice ... can only be made by the Lord.'

In his fifteen-page judgment, the judge concluded that: 
[we are] sorry to state that both of them [the victim and her mother] have turned their back towards the case of the prosecution and have not at all on any material particular supported the case of the prosecution.

He based himself on several decisions, some very old, which the defence counsel had quoted during the closing arguments concerning the admissibility of evidence. He concluded that:

Confronted with the evidence discussed, finding recorded and law cited supra, this court is left with no option except to hold and conclude that the prosecution has miserably failed to prove its case beyond reasonable doubt.

\section{/p. 109/}

Nevertheless, during my conversations with the judge, he did not seem to have any doubt of the fact that the girl had regularly been raped by the young man. He knew also that the girl's mother continued to live in the father's house and that she had now received, as he said, some 'compensation'. This, indeed, was what he had already suggested at the time of the cross-examination during which, speaking in the name of the prosecutor, he had dictated several formulas indicating the reasons which would have pushed the girl's mother into denying the accusations. But, as the judge explained to me later:

From a legal point of view it is different. Imagine that you said that someone had slapped someone else across the face and you came immediately to tell me that. Your evidence, even if it is indirect, will be relevant because it will be able to corroborate the evidence of the victim. But suppose that the person struck comes to tell me that that they have not received any slap from anyone: then your evidence is no longer relevant, it becomes second-hand. You know, it is very difficult to be a judge in these cases...

With regard to the accused he also told me that

we have no sympathy for the accused [...] even if you think that he is a criminal you cannot do anything. We are strictly bound by the provision; what the law states we can't overview that; [I think that] judges should be free to decide the case in many manners. 
Although outside of the court or at the time of the presentation of evidence, the positions of the judge and the prosecutor were close both were convinced that the girl and her mother were lying - when it came to the closing statements and the judgment, their positions diverged on the legal validity of the other testimonies: the judge assessed that they arose from hearsay whereas the prosecutor stressed that they were credible. This divergence of position, which I noted at the time of the trial, has nevertheless been attenuated with time. Almost a year after the judgment, when I returned to the area, I once again paid a visit to the prosecutor and asked him if the case had been sent to appeal. He replied that this case was not appropriate for an appeal as the medical report was in the end not very clear and that it would not have been sufficient to have the accused convicted. $\mathrm{He}$ therefore asked his assistant to go and get the case-file to show me the report that he had made to the government, it being incumbent on the prosecutor to forward the file together with his advice on the necessity that the case be re-examined in the High Court of the State. ${ }^{18}$ But something inexplicable for him had happened: the case-file had disappeared; it had not been sent to the government and no withdrawal of it had been marked in the register. The prosecutor's assistants searched for the file for several days but without success. Rumours began circulating about another prosecutor who may have had the file disappear at the request of the accused's father so as to be sure that the case could not be sent to appeal. The prosecutor told me that he would open an enquiry into this, but up to the present the file has not yet be found.

\section{The account of the affair in the village}

The understanding of the local social context that the professionals involved in the matter (police, prosecutor, judge) showed when they discussed it outside the courtroom, while broader than what comes out of the exchanges that were verbalized and translated at the time of the trial, provides a picture of a village community completely dominated by local power relationships. In the victim's village, nevertheless, the story of the girl and her aggressor, as told by one of the people involved in it, takes on another depth. It shows up characters who are more nuanced than those who appeared 
before the judge, but also that the case, such as it arose out of the investigations and the court /p. 110/ process, was not the final act of a story whose beginning was much older and certain dynamics of which went entirely unmentioned before the representatives of the official form of justice.

Nearly a year after the trial, the school-teacher revealed to my assistant that at the start, when the girl had told her what had happened, her reaction had been to try and arrange things with the family of the aggressor. Here are a few passages from her story:

She [Anita] wasn't well and at the beginning her mother had told me that she had gall-stones. I believed her and I even suggested getting some treatment and getting help from them (the family she was working for) [...] But the girl got worse and worse. She was always sick, was no longer doing her homework, she wasn't eating and was spending all her time crying in a corner. I called her into my office and I insisted she tell me what was the matter. That was when she told me what had happened but said that she had been told not to talk to anyone about it [...] She was terribly frightened [...] She said that the young man's mother had threatened to cut off her head if she talked. She then said to me 'Madam, take me home with you, otherwise she [the young man's mother] will kill me.' I immediately understood everything. I also realized why the parents of the boy had begun to send me lots of vegetables and fruit some time back. They were sending large amounts of vegetables and I didn't understand why.

The signs of Anita's problems had thus shown up before the school-teacher discovered the bleeding and sent the girl to the hospital. To stay crying in a corner, not eating, not doing her homework were the only ways Anita had to show her distress to the teacher without being able to speak. The school at the time represented the only place where she could feel protected, where she could attract attention of someone to help her tell what she was being forced to keep quiet about. One also sees how at this point the young man's parents, who were aware of what he was doing to the extent that they had threatened to kill the girl if she said anything, began to fear that the teacher had been informed of the matter. Perhaps taking advantage of the caste relationship between her and their family (both were Brahmins), they sent 'gifts' to create what the teacher called 'good relations' which could have predisposed her not to believe what 
the girl (coming from a Scheduled Caste) might have said against them. But then, once the bleeding became obvious, the teacher was able to convince Anita to tell her everything, which, according to the account presented at the trial, would have set off the official involvement in the issue (medical examination, official complaint, involvement of the police etc.).

But in fact, Anita's revelations had not, in the first instance, led the teacher to involve the state justice system. This is how she continued her story:

The young man's father had admitted that what his son was doing was not right, but he asked me not to call the police: he would have done anything that I asked him. He made use of someone on the school staff to offer me money so that I did not say anything to the police. So I asked him to put 400,000 rupees into a bank account in the girl's name and to put some land in her name. From that time on the girl was finished, ${ }^{19}$ her situation was deplorable. He told me that he agreed, that he would do that but that I shouldn't call the police. [...] But the police started coming to the village because someone had told them something [...] [The police] were creating a lot of problems for us and were saying to me 'Madam, why won't you give evidence?' But we hadn't said anything, we did not want to help the police at that moment. If there could have been a compromise, that would have been good because in court the case would go on and on...

Even when Anita had told the teacher everything, the latter had decided that the affair should be sorted out locally. The fact that the accused was someone from the village, and was of the family on whom the girl's mother depended for her survival, had led the teacher to prefer the path $/ \mathbf{p . ~ 1 1 1 / ~ o f ~ c o m p r o m i s e ~ t o ~ t h a t ~ o f ~ t h e ~ s t a t e ~ j u s t i c e ~}$ system. The very hostility that she showed towards the police officers who were 'causing them a lot of problems' and to whom she did not want to say anything, would seem to confirm the theory of the 'alien state', of the existence of an opposition between the justice of the state and village practices for the resolution of conflicts. But things suddenly changed, as she herself mentioned:

Then one day, I was passing in front of their house [of the young man's father] and I then told him that I was going to call the pradhan [the village headman] so that he could effect the transfer of 
the money and the land to the name of the girl, and you know what happened? The girl's mother, who was standing beside him, said to me: 'What are you saying, Madamji, why should we take his money? Why are you insulting him?'Well then I didn't want to know anything more. You realize? That was her mother! And what she had told me when she came to the school was completely different. She had asked me to help her, that she did not know how to get out of that situation, that she needed the work that she was doing at their place because she had two children to feed. She had even concealed her coming to see me because they had forbidden her to come to the school. I had tried to help her and now she was talking to me like that! I was so furious that if I had been closer to her I would have smashed her head in. So I told them that I was going to call the police.

The fact that the crime was not going to be repaired by a compromise, and that it was even being denied by the victim's mother, led the mistress to change her idea: it was now up to the state to intervene, not only to indemnify the girl but also to punish the offender. This change was provoked by the attitude of the mother, who had finally let herself be dominated by her master. She had nevertheless shown that she was also trying to react against her position of subjection when she had been to see the teacher on the quiet to ask her for help. It was when the local methods of providing compensation were not properly activated and when the dominant power relationships asserted themselves that the teacher fell back on the state justice system. As a result, the gap broadened between the local dominance strategies and the logic of the law. But the positions and reactions of the victim's family differed, as shown in the rest of the teacher's account:

From that day on they stopped the girl coming to school. They were afraid that the police would arrive and take her statement. Then I received a call from the pradhan who told me 'the police are here, they want to question the girl', but I told him that for days she had not been there, there was only her little brother. Then, along with my colleague, we had the idea of asking the boy if he knew what had happened to his sister. And you know what? He told us everything! And what a horrible picture he gave! It was incredible! So I immediately called the pradhan back to tell him: 'Quick, the boy knows everything. He must be taken to the police so he can give evidence.' The pradhan came, lifted the little boy up and took him 
to the police. And the little fellow told them everything. We were very happy to see how brave he was, the little chap.

The boy was only seven, but because he was not the immediate victim, he may have felt less directly threatened than his sister by the prohibition on talking. It was finally thanks to him that a connection between the official justice system and the locality was able to be established. He would tell everything, first to the police and then to Karam Chand the social activist for the Scheduled Castes who, in view of the young age of the boy, would finally take responsibility himself for laying the official complaint. Nevertheless, the boy's story was not incorporated by the prosecutor who did not include him in the list of witnesses as he thought that, like his sister, the boy too would have been forced to deny everything before the judge.

Now that the trial was over and the accused had been acquitted and was back in the village, the teacher was not at all happy with the way things had ended up. She told my assistant that the youth's father had just organized a big ceremony at his home in honour of the village deity in order /p. 112/ to thank her for having helped his son to be acquitted. As for the teacher, she from then on was afraid to meet people from his family who stared at her full of anger.

It is very dangerous for us. You know for example what the boy did when he got out of prison? He came down here during the holidays one night and smashed up all the school's toilets. They had just been refurbished and he totally smashed them with big stones.

Although Dhiman's father had now built a little house for the girl's mother and her two children, the teacher thought that justice had not been done, and that the young man should have had to stay in prison much longer.

The judge should have based his judgement on the medical report. It is not good enough to say that nothing could be done. Had the doctor been mistaken, then? Well, if she had been mistaken, then there should have been disciplinary measures taken against her. Or there should have been another medical examination called for. It can't finish like that! The judge should have based his judgement on what the doctor said, and if the mother had retracted he should have understood why. [...] We tried to ensure that that little girl was given her rights... 
Having opted for the justice of the state, the school-teacher was now protesting against the decision of the judge and was adopting the language of rights. She could have been satisfied with the fact that the father had in the end had a house built for Anita and her family (as well as the money that he may have given them). But that was not the 'compromise' that she had initially desired, one which would have had to be adopted before the pradhan and which recognized the crime before the village community. What she could not accept was that the trial had publically established that the offence had not effectively taken place, and that her evidence, that of Karam Chand and that of the doctor had not been enough to have the accused convicted.

\section{Conclusion}

The Indian courts have often been defined in anthropological studies as institutions that are blind to the local context and the networks of social relations in which a person is caught up. Nitya Rao, for example, notes how in the courts of Jharkhand 'the local context is largely ignored in favour of the notion of universal rights.' $\mathrm{He}$ observes also that 'the exclusion of local discourse implies that decisions taken here [in the court] are hardly implemented on the ground' (2007: 316). These ideas are often the consequence of a scholarly approach of the courts which for a long time has had as it principal concern to contrast state justice with the village councils, the panchâyat, or other forms of arbitration process at the village level (Cohn, 1959; Hayden, 1984; Moore, 1993). They correspond also to the image that certain judges want to give of themselves as neutral arbiters whose decisions are based purely on the 'established facts' and on the rules of evidence.

The ethnographic data that have been presented nevertheless show how the social dynamics in which a court case is embedded are a regular subject of conversation among the professionals in charge of the case. These dynamics are also used during trials in the form of arguments suggesting the reasons for which witnesses are suspected of not telling the truth. In the case discussed in particular, they were evoked by the judge and by the prosecutor in relation to the victim's mother, to suggest that she had received compensations from the accused's father, or to emphasize the economic dependence linking 
the mother to the accused's family. They were brought up also by the defence counsel to formulate his theory of a plot. These disparate references to the sociological context at the time of the trial often assume a strategic value, whose goal is to undermine the credibility of a witness or to suggest why that witness had turned 'hostile', according to the judicial /p. 113/ expression of such a circumstance. They give the impression of supplying conventional explanations, more intended to be taken into account by the judges than to contribute to the search for the truth, for they are recorded in writing at the very end of a transcript, as the conclusive statements of the cross-examination, and sometimes directly in English.

Even if the judge's decision and the prosecutor's report definitively constitute an explicit recognition of the fact that private negotiations between the parties prevailed over justice of the state, what emerges from the court sittings - and in particular what is verbally expressed - nevertheless shows how the judge and the prosecutor can focus, according to the phase that the trial is at, on understanding the case in sociological terms or, in contrast, comprehending it in legal terms.

Paradoxically, it is the victims themselves, if they retract their statement, who deny any influence of the social dynamics at the time of the trial. But it would be incorrect to present their retraction as a simple demonstration of the opposition between the judicial system and the village system. The example presented here shows how, in the case of the residents of the village, the same people are able, according to the moment or the circumstances, to fit in with the dynamic of the local power relationships or, on the other hand, to adopt the logic of the law. We have seen how Anita, although terrorized by the threats made against her, nevertheless managed to attract the attention of the school staff and tell what had happened. Equally the mother, though in the end completely controlled by her landlord, had tried at a particular time to escape from this domination by going secretly to meet the teacher and ask her for help.

If in the case of the girl and her mother, their passing back and forth between a state of mute subordination and their open declaration of the crime is ambiguous, depending on their capacity to resist the pressures and threats coming from their masters, in the case of the teacher this change showed up in more sharply delineated fashion and resulted from the impasse into which the local procedures for compensation seemed to have fallen. As for Karam Chand, he shows 
the manner in which, in this same social milieu of economically disadvantaged and socially subordinated castes, certain individuals have completely abandoned the village processes for the resolution of conflicts and have become mobilized to put into practice the principles of equality enshrined in the law.

It would be overly reductive to interpret these changes in attitude on the part of the protagonists purely in terms of manipulations or resistance. An approach focused on the actors (Lewis, 1993) which takes into account not only the official verbal exchanges of the trial but the individual accounts of the various protagonists, may allow for a better restitution also of the subjective dimension of the relationship which villagers have with the state judicial procedures. It may show also how an approach to practices of justice which is concerned only with analysing, or even with denouncing, the colonial origin of the judicial categories and procedures, or the way in which they continue to reproduce the relationships of power and subordination, while being pertinent from a historical perspective, would not be sufficient to restore the multiplicity and variability of the attitudes and behaviours of the actors concerned, their solidly-held ideas, their passions or their hesitations.

Translated from the French by Colin Anderson

\section{Notes}

1. This article is a result of the French ANR research programme (08-GOUV-064) entitled 'Justice and Governance in India and South Asia' (www.just-india.net).

2. Brown (2003), Baxi (2003) and Guha (1989). For an analysis of the history of these theories, see Wardhaugh (2005), Luden (2001) and Sivaramakrishan (2008). The idea of a resistance is also implied by the idea of using the law as a 'weapon of the weak' (Eckert, 2006).

3. The term 'bi-legal' refers to the fact that villagers could use both the indigenous system as well as the official law, depending on their estimation of what was in their interests (Srinivas, 1962).

\section{/p. 114/}

4. The practice of translating and transcribing the witnesses' depositions into English is followed in most of the states of the Indian Republic. There are nevertheless some exceptions, as in the State of Punjab, where the depositions are transcribed in Punjabi.

5. The repetition of the accusations is made even when the judge sees that the charge cannot be proved by the prosecutor, this being a procedural obligation. The 
questions are then read aloud by the court reader or directly transcribed by the clerk in the presence of the prosecutor and defence counsel.

6. This meticulous work of dictation and transcription derives its whole sense from the anticipation of an appeal, on which occasion the facts will be once more, and several times, narrated.

7. The names of all those involved in the affair have been changed so as to preserve their anonymity.

8. The Indian Code of Penal Procedure is part of a codification project begun by the British in India from the first half of the 19th century.

9. Consultable on-line at:

http://ribal.nic.in/WriteReadData/CMS/Documents/201303131039493105468po

aact989E4227472861.pdf.

10. Such cases also required to be heard by a special court, even if it is often the Session Judge who oversees the case.

11. Meaning referring to the 'dharma', the principle of cosmic and social order (and the rules of conduct that allow it to be preserved).

12. The case presented here also clearly brings out the nature of the power relationships between high-caste and low-caste families. Everything took place here within an environment of relative familiarity: the girl knew her aggressor, she called him ' $m a m u$ ' (maternal uncle); the rape was committed in the house of her master, in the room where she slept with her mother and brother, and where the accused often came to watch television with them. These people belonged to very different castes but lived in a relation of proximity due the dependence of the work situation. The fact that the rape episode was registered under the Sc/St Act was the consequence of an abuse of this relationship of dependence and familiarity.

13. Lawyers also sometimes go as far as constructing 'evidence' of these constructed plot stories, by making use of disputes which are possible or potential within the cultural context considered. They may try to show, for example, that the real dispute between the parties has nothing to do with caste discrimination and that the case has been entered under that Act simply to transform a matter treatable under the civil code into a criminal affair implying the immediate arrest of the accused.

14. This theory is moreover generally already presented by the accused at the beginning of the trial when the judge asks him if he declares himself innocent - and thus if he wishes to proceed with the trial. An example being a statement like: 'The accused has taken up a defence of complete denial and claimed that the official and interest witnesses have deposed against him only. He is innocent. He has been falsely implicated by the enemies of his father in the village.'

15. The reports in the press, the accounts of close relatives and friends, the evidence presented at the trial and the indications in the text of the judgment are not uniform as to the period over which the rapes were repeated, varying from two months to two years.

16. These sentences were dictated directly to the clerk of the court in English and were thus not understood by the girl. Although they are presumed to reproduce the question-answer exchanges which took place during the trial, they reproduce in fact the sentences such as they had been written in the police report. On the other hand, the questions put to the girl in Hindi during the trial are formulated in a language more adapted to a child, particularly for the sexual terms.

17. When I began following the sittings, the trial was already underway. 
18. The previous year I had not seen his report because I had to leave the area before the prosecutor had drawn it up.

19. The idea expressed by the teacher is that when a girl has been raped she will no longer be able to marry.

\section{References}

Anderson M.R. (1990) Classifications and coercions: themes in South Asian legal studies in the 1980s. South Asia Research 10(2): $158-177$.

Baxi U. (2003) The colonialist heritage. In P.L. Munday and R. Munday (eds), Comparative Legal Studies: Traditions and Transitions. Cambridge: Cambridge University Press, pp.46-75.

/p. 115/

Berti D. (2010) Hostile witnesses, judicial interactions and out-of-court narratives in a North Indian district court. Contributions to Indian Sociology 44(3): 235-263.

Berti D. (2011a) Trials, witnesses and local stakes in a district court of Himachal Pradesh (North India). In J. Pfaff and G. Toffin (eds) Citizenship, Democracy, and Belonging in the Himalayas,. New Delhi: Sage, pp.290-313.

Berti D. (2011b) Courts of law and legal practice. In I. Clark-Decès (ed) A Companion to the Anthropology of India. Oxford: Blackwell, pp.355-370.

Brown M. (2003) Ethnology and colonial administration in nineteenth-century British India: the question of native crime and criminality. British Journal for the History of Science 36(2): 201-219.

Cohn B.S. (1959) Some notes on law and change in North India. Economic Development and Cultural Change 8(1): 79-93.

Cohn B.S. (1965) Anthropological notes on disputes and law in India. American Anthropologist, 67(6) The Ethnography of Law: 82-122.

Davies M., H. Croall and J. Tyrer (1995) Criminal Justice: An Introduction to the Criminal Justice System in England and Wales. London: Longman. 
Eckert J. (2006) From subjects to citizens: legalism from below and the homogenisation of the legal sphere. Journal of Legal Pluralism 53-54: 45-75.

Galanter M.L. (1992) The aborted restoration of 'indigenous' law in India. In M.L. Galanter, Law and Society in Modern India (introduction by R. Dhavan). Delhi: Oxford University Press, pp.37-53.

Guha R. (1989) Dominance without hegemony and its historiography. Subaltern Studies vi: Writings on South Asian History and Society. Oxford: Oxford University Press, pp.210-309.

Hayden R. (1984) A note on caste panchâyats and government courts in India: different kinds of stages for different kinds of performances. Journal of Legal Pluralism 22: 43-52.

Kolsky E. (2005) Codification and the rule of colonial difference: criminal procedure in British India. Law and History Review 23(3): 631-683.

Lewis H.S. (1993) A new look at actor-oriented theory. PoLAR (Political and Legal Anthropology Review) 16(3): 49-56.

Ludden D. (ed) (2001) Reading Subaltern Studies: Critical History, Contested Meaning, and the Globalisation of South Asia. New Delhi: Permanent Black.

Merry S.E. (2003) Rights talk and the experience of law: implementing women's human rights to protection from violence. Human Rights Quarterly 25(2): 343-381.

Moore E.P. (1993) Gender, power, and legal pluralism: Rajasthan, India. American Ethnologist 20(3): 522- 542.

Moore H. (1994) The problem of explaining violence in the social sciences. In P. Harvey and P. Gow (eds) Sex and Violence: Issues in Representation and Experience. London: Routledge, pp.138-155.

Rao N. (2007) Custom and the courts: ensuring women's rights to land, Jharkhand, India. Development and Change 38(2): 299-319.

Roussel G. (2005) Les procès-verbaux d'interrogatoire : Rédaction et exploitation. Paris: L'Harmattan.

Shah A.M. (1998) The Family in India: Critical Essays. New Delhi: Orient Longman.

Sivaramakrishnan K. (2008) Some intellectual genealogies for the concept of everyday resistance. American Anthropologist 107(3): 346-355. 
Srinivas M.N. (1962) Caste in Modern India, and Other Essays. Mumbai: Asia Publishing House.

Stein B. (1980) Peasant, State and Society in Medieval India. Delhi: Oxford University Press.

Wardhaugh J. (2005) The jungle and the village: discourses on crime and deviance in rural North India. South Asia Research 25(2): 129-140. 